\title{
SOTERIOLOGICAL STUDIES ABOUT THE CONCEPT OF CHOICE GOD ACCORDING TO ROMANS 9:6-16
}

\author{
Fernando Nababan ${ }^{1)}$ Widi Prasetyo ${ }^{2)}$ Ani Teguh Purwanto ${ }^{3)}$ Daniel Ari Wibowo ${ }^{4)}$ \\ 1) Evangelical Theological Seminary of Indonesia - Surabaya \\ E-mail:fernando@sttii-surabaya.ac.id \\ ${ }^{2)}$ Evangelical Theological Seminary of Indonesia - Surabaya \\ E-mail:widiprasetyo@sttii-surabaya.ac.id \\ 3)Evangelical Theological Seminary of Indonesia - Surabaya \\ E-mail: aniteguhpurwanto@sttii-surabaya.ac.id \\ 4) Evangelical Theological Seminary of Indonesia - Surabaya \\ E-mail:danielariwibowo@sttii-surabaya.ac.id
}

\begin{abstract}
God acts to choose a person or group and within a larger community, for a purpose or future of His own choosing. The main OT word for this word is bak-har (bak-har), which means to choose someone or something carefully, after carefully considering other possibilities. This word includes the mind, is very fond of the chosen thing, and sometimes receives pleasure from it. In the LXX and the NT the verb which corresponds to ba-khar is eklegomai. In ancient Greek this language was usually used in an active sense, and the biblical writers used it in a form meaning to choose for himself. (Hareomai) Haireomai, used of God's election in 2 Thess 2:13, and in Deut. 26:18 LXX, with the same meaning.

The Hebrew verb (yada) (yada), meaning to know which is used for various ways of knowing, at least in the mind, containing and expressing love such as sexual relations, or confession on the part of one who believes in God is used in Gen. 18:19; Hos 13:5 concerning the election of God means knowing God in love. Likewise, the Greek word proginosko meaning "to know beforehand" is translated "He chose" in Romans 8:29. Election is a fully sovereign act of God; Allah is in no way obligated to choose anyone because everyone has lost his position before Allah. Even after Christ's death, God was still under no obligation to carry out salvation. Except that He had to keep the agreement He had made with Christ regarding the salvation of mankind. So, God's election is a fully sovereign act because there is no coercion from anyone.
\end{abstract}

Keywords: Choose, KeJustice, God's Will, Holiness. 


\section{INTRODUCTION}

As a believer, a believer must know the God he worships. If believers do not know Him how can they glorify Him. Theology also means living God's love for us and our love for Him. ${ }^{1}$ In Proper's theological doctrine it has been explained about the person of God himself.

The attributes of Allah are the perfections that do exist in Allah. ${ }^{2}$ Often believers understand God's attributes not fully, and this makes some people unable to accept all of God's attributes at work in their lives. Many people only understand that Allah is Most Loving, Allah is Most Gracious, Allah is Most Holy and Most Present. But there are attributes of God that are often overlooked by many believers, namely God's Omniscience and Justice (specifically in the Doctrine of Election).

Believers need to accept the truth about God's existence by faith. Talking about faith is not just in words, but must also know it through the Word of God by special revelation as well as through this universe as general revelation. Because one's view of God can even be considered as the general frame of reference within which one constructs one's theology and also lives one's life. ${ }^{3}$ When one emphasizes that Allah is all-loving, regardless of other aspects of Allah's attributes, one will come to the wrong conclusion. Many people love a loving God, but they don't want a holy God or a just God. ${ }^{4}$

It should be underlined, when a person believes in the existence of God, he must also believe in His statutes.

God's sovereignty is one of God's attributes and with this sovereignty He rules all of His creation. To be sovereign must be omniscient, omnipotent, and absolutely free. God's sovereignty demands that He is absolutely free, and that means that He can be free to do whatever He wants anywhere and anytime. It is to carry out His eternal plan to the smallest detail without any hindrance. If $\mathrm{He}$ were not absolutely free, then $\mathrm{He}$ could not have absolute sovereignty. ${ }^{5}$

\footnotetext{
1 “Tabloid Reformata" Edition 66, year V September 2007

${ }^{2}$ J. Wesley Brill “Tough Basis" KALAM HIDUP Publisher/ Jl. Naripan 67- Postbox 156 Bandung. Matter. 45

${ }^{3}$.https://kupdf.com/download/teologi_59b6ada408b bc5390c7a9526_pdf in the post 11 september 2017. Page 13
} 
To be the sovereign Person of God means to be the supreme giver and executor of all laws. God's law is divine, both in authority, power, and eternity. ${ }^{6}$ This includes God's law of justice.

God's justice for His elect is often a matter of debate for some theologians. We have already noticed that God Himself acts according to the laws $\mathrm{He}$ has established. ${ }^{7}$ God's plan never changes. When humans fail, they will cause regret, which means revising other people's judgments and changing their plans of action. God never did that. ${ }^{8}$ But the shallowness of human understanding of the person of God, makes humans often make a wrong interpretation of God's election. Not even a few people think that God has failed in His plan, when He chose the nation of Israel as His chosen nation.

\section{RESEARCH METHOD}

To exegesis Romans 9:6-16 on "The Concept of God's Choice" the author uses a research method with a qualitative approach of literature study. Qualitative research method is an approach in which research

\footnotetext{
${ }^{6}$ John M. Frame "The Doctrine of Knowledge About God" Department of Literature Saat/ Jl. Arief Mergono 18, Malang 65117

${ }^{7}$ Millard J. Erickson “Christian Theology” Gandum Mas Publishing Foundation/Box Post 46- Malang 65101, East Java. Matter. 373
}

findings are not obtained through statistical procedures or other forms of calculation, but this procedure produces findings obtained from data collected using various means. In this case the author uses a qualitative method of literature study.

Conducting a survey of existing data is a very important step in the scientific method. Searching the existing literature and studying it diligently is a library work that is indispensable in doing research.

\section{RESULTS AND DISCUSSION}

\section{Grammatical Analysis}

Roman Grammar. 9:6-16 "God's Chosen

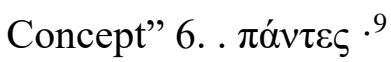

God's Word It is impossible to fall down : adverb, from the root, which means: no , : adverb, from the root, which means: like, like that. In the Greek Indonesian Interlineaer means impossible. ${ }^{10}$ : coordinating conjunction, from the root, which means but, and. : conjunction, from the word, which means: that, since, because. : verb, indicative, perfect, active, third person singular, which means: he is constantly falling (has failed). This word

\footnotetext{
${ }^{8}$ JI PACKER "Practical Guide to Knowing God" ANDI Foundation Publisher, Jl. Beo 38-40, Yogyakarta 55281. Pg. 87

${ }^{9}$ Bible Work 8

${ }^{10}$ Rev. Hasan Sutanto "Greek-Indonesian Interlinear New Testament and New Testament Concordance" Volume I Indonesian Bible Institute. Matter. 848
} 
can mean falling down (Mark 13:25) in a figurative form it means: loose, lose, fall (Gal. 5:4) while in this verse it means failure. ${ }^{11}$

This word is contradicting the accusation that it is as if the words that Paul preached on the basis of the Old Testament are no longer valid. ${ }^{12}$ : definite article, nominative, masculine, singular, from the root, which means, that. : noun, nominative, masculine, singular, from the root, which means: word, word, word, saying. : definite article, genitive, masculine singular, from the root, which means: that. .: noun, genitive, masculine, singular, from the root , which means: belongs to God. : adverb, from the root: , which means: no. : coordinating conjunction, from the root word, which means: cause. : adjective, infinitive, nominative, masculine, plural, from the root: all, all. : article, nominative, masculine, plural from the root: which means: people who. : preposition, genitive from the root: which means to come out of. : noun, genetic, masculine, singular from the root which means belonging to Israel. : hint pronoun, nominative, masculine, plural from the root which means, these people.:

\footnotetext{
${ }^{11}$ Dr. Robert J. Leland, D. Min., et al. "Revised Analytical Lexicon of Greek" Randa's Family Press, Jogyakarta 55571. p. 117

${ }^{12}$ Dr. Th. Van Den End "The interpretation of Rome” BPK Gunung Mulia, Jl. Kwitang 22-23, Jakarta. Matter. 438.
}

noun, nominative, masculine, singular from the root which means Israel.

Grammatical EYD Termahan: That the Word of God could not have failed, because not all the people who came out of Israel were Israelites. While the LAI Translation: but the word of God cannot fail. Because not everyone who comes from Israel is an Israelite. Verse 6 shows the unity of the NT and OT so that accusations from the OT can be answered by starting from the OT as well. That is why Paul's letters in the NT contain so many quotations from the OT. $^{13} 7 ., \cdot .^{14}$

Not all who come from the seed are the children of Abraham (son of the promise) : coordinating conjunction, from the root which meansand, even, neither.: conjunction, from the root, which means: that, since, because. Usually a conjunction serves to connect two or more words, phrases, clauses, sentences or paragraphs, thus clarifying the relationship between the two elements. While the clause that is preceded by a subordinate conjunction is called a conjunctival clause and functions as a substantive or as an indirect discourse. ${ }^{15}$

\footnotetext{
${ }^{13}$ Ibid Hal. 427

${ }^{14}$ Bible Work 8

15 John D. Grassmick "Principles and Practice of Greek Exegesis” pp.71-75
} 
Connecting words between sentences serve to explain the reason or basis of the previous sentence. ${ }^{16}$ : indicative present verb, O3, plural from root: which means: they are taking place is. $\sigma \pi \varepsilon \varepsilon \rho \mu \alpha^{17}$ : noun, nominative, neutral, from the root: which means seed. : noun, genitive, masculine, singular from the root Which means: belongs to Abraham. : adjective, infinitive, nominative, masculine, plural, from the root: which meansall, all. , : noun, nominative, neutral, plural from the root: which means children. $:$ coordinating conjunction, from the root: which means but, except. This word is also useful for proposing a sentence with sharpness and stress. ${ }^{18}$ : preposition, dative from the root: which means inside. : noun, dative, masculine, singular from the root: which means Isaac. : verb indicative future passive, o3 singular, from the root: which means he will be called, given a name. : personal pronoun, dative, singular from the root: which means inside. : noun, nominative, neutral, ${ }^{19}$ from the root word: which means seed, offspring.

\footnotetext{
${ }^{16}$ Saparman "Learning the Bible" STTII Press Yogyakarta, 2007 p. 143

${ }^{17}$ It should be noted that the term Sperm in verses 78 is different. Offspring (Sperm=Seed) denotes the broad circle of all people born of Abraham 7a. Whereas in verses $7 \mathrm{~b}$ and 8 , the so-called offspring (sperm) are the limited environment of the chosen people.
}

EYD Grammatical Translation: for neither those who are Abraham's seed are all children of Abraham, but the seed in Isaac will be named. The word provides a sharp sentence to emphasize that it is the seed that was in Isaac that will be named or accounted for. Then the Indonesian Bible Society translated: and also not all those who are counted as descendants of Abraham are children of Abraham, but those who come from Isaac who will be called your descendants. So what Paul's thought about salvation is that Abraham's promise was limited to the descendants of Isaac. ${ }^{20}$

"God's Choice Is Not Only Based On Sperm (Seed), But Also Based On A Promise" From the grammatical study shows that God's choice is clearly not based on Abraham's children according to seed ( $\sigma \pi \varepsilon \dot{\rho} \mu \alpha$.$) , but God's choice is clearly$ visible, namely on the promise ( ) God's Word, which he had established through Isaac (God's promised son). Greek: ( $\left.\dot{\pi} \pi \gamma \gamma \varepsilon \lambda i \alpha^{\prime}\right)$ agreement, promise, guarantee this is dominated by God's proclamation

\footnotetext{
${ }^{18}$ Dr. Robert J. Leland, D. Min., et al. "Revised Analytical Lexicon of Greek" Randa's Family Press, Jogyakarta 55571. p. 15

${ }^{19}$ Baker "Analytical Greek New Testament" BAKER BOOK HOUSE, grand Rapids, Michigan 49506, p. 491

${ }^{20}$ Thomas R. Schreiner "New Testament Theology" Publisher Andi yogyakarta, p. 236
} 
which provides assurance of what $\mathrm{He}$ intends to do.

The promise becomes a solid foundation in God's justice for the choice on the basis of that promise confirms Word of God. Because : verb, indicative, perfect, active, third person singular, which means: he is constantly falling (has failed, fell), preceded by the adverb meaning impossible. In verse 6 Paul begins this word, that the Word of God has never failed and is sure to be fulfilled by God Himself. Furthermore, in verse 11 , it is further clarified, that the choice is also seen not because of actions, namely a good or valuable thing. It is very clear in the words and are the two adjectives that follow

the verb $\pi \rho \alpha \dot{\sigma} \sigma \sigma \omega$, (in the active aorist form) which means that God makes a choice not because the chosen object has done or done something good or valuable. But the choice is in accordance with the awaited God's choice using the word . His choice of Israel, as a community of people to complete God's plan.

\section{Lexical Analysis}

from root (Indicative Verb, Perfect) pipto "fall", used (a) derivative, to "fall" down from, is likened to a bird because it was God who sent it down. Mt 10:29; fall from the hand that holds 13:4; (b) "fallen" under judgment, James 5:12 (see Rev. 18:2, $\mathrm{RV);} \mathrm{(c)} \mathrm{falling} \mathrm{down} \mathrm{usually} \mathrm{when} \mathrm{people}$ are in the act of prostration, to prostrate themselves, Mt 17:6; John 18:6; Revelation 1:17; in reverence and worship, Mt 2:11; Mark 5:22; Revelation 5:14; 19:4; (d) things, "fall" into ruin, or failure, Matt. 7:25; Luke 16:17, "fell," because of the $\mathrm{KJV}$, "failed" (e), "fallen" in judgment on people, as in the heat of the sun, Revelation 7:16, "strike," KJV, "light"; fog and darkness, (f) people, in "fall" morally or spiritually, Rom 14:4; 1 Corinthians 10:8,12; Revelation 2: 5.

Apopipto (a) popi "fallen from" (apo, "from"), used in Acts 9:18, like the membrane that "fell" from Saul's eye.

ekpipto, falling from (oak, "out", and No. 1), "is used in the NT, literally, like a flower withered by the laws of nature, James $1: 11$; 1 Peter 1:24, like a ship out of control, this was experienced by Paul when the ship he was on ran aground.Ac $27: 17,26,29,32$, like a shackle released from the wrist of a prisoner, 12:7; figuratively speaking, from God's Word (an expression of His purpose), which cannot "fall away" from the appointed end, Rom 9:6; Friberg interprets it as a figure of speech as well, namely the non-fulfillment of a divine promise which fails or loses the effect of that promise.Gingrichmeaning it fails or weakens, just like the comparison between 
Journal Kerugma

E-ISSN: 2622-1039

P-ISSN: 2621-8038

love never ends, but tongues will cease and knowledge will pass away (1 Cor 13:8).

About the believer they are warned that he does not "fall" not to be drawn astray from the path that God's Word has set out, 2 Peter 3:17. " this word is also used by Paul to express true freedom by Christ. So from those who seek to be justified by the law, Gal 5:4, "you have fallen from grace", apart from grace.

Empipto, "to fall into, or between" (en, "in", and No. 1), is used (a) literally, Mt 12:11; Luke 6:39(b) metaphorically, in condemnation, 1 Tim 3:6; reproach, 3:7; temptation and snare, 6:9; the hand of God in judgment, Heb 10:13.

Epipipto "fallen up" (epi, "above," and No. 1), used (a) literally, Mark 3:10, "urgent"; Acts 20:10,37; (b) metaphorically, afraid, Luke 1:12; Acts 19:17; Revelation 11:11 (No. 1, in several ms.); reproach, Rom. 15:3; of the Holy Spirit, Acts 8:16; 10:44; 11:15am.

Note: Some mss. have this verb in John 13:25; Acts 10:10; 13:11.

Katapipto "fallen" (word, "down," and No. 1), used in Luke 8:6 (in best mss.); Acts 26:14; 28:6.

Prospipto, "to fall upon anything" (pro, "toward"), "to strike," is said of "the

${ }^{21}$ VINE'S Expository Dictionary Of Biblical Words. PC Study Bible V5.0C for Windows. Computer Software. wind," Matt. 7:25; it also signifies "falling" down at one's feet, "falling down" before prostrating, Mark 3:11; 5:33; 7:25; Luke $5: 8 ; 8: 28.47$; Acts 16:29.

Hustereo "come late, be last, behind, inferior," translated "fail) in $\mathrm{Heb}$ 12:15, RV, for KJV," fail," and "fall short" in Rom 3:23, for KJV," come short, "which, given the previous "has," is ambiguous, and can be thought of as the past tense.

Parabaino "to go beyond, to fall" (para, "away, across," baino, "to go"), translated "to fall far" in Acts $1: 25, \mathrm{RV}$, for the KJV, "with the transgression of falling."

Katabaino (katabai) denotes "coming (or falling) down," Luke 22:44; in Revelation 16:21, "come down,". ${ }^{21}$

use

1oor. ; 2aor; pf. ; basically falling from or down; (1) literally; (a) like withered flowers that fall (James 1.11); (b) the shackles of falling or falling (KPr. 12.7); (c) as a nautical technical term, ships drifted, pushed against rocks, ran aground (KPr. 27.17); (2) figuratively; (a) lose the favor or grace of loss, no longer experience (Gal. 5.4); (b) non-failure of divine promise, loss of effect, influence or effect (Rom. 9.6) 22 In Rom 9:6

eppipto, has the meaning of losing

\footnotetext{
${ }^{22}$ Friberg, Analytical Greek Lexicon. Bible works 10 for windows. computer software
} 
Journal Kerugma

E-ISSN: 2622-1039

P-ISSN: 2621-8038

validity, failing. But not seen in the LXX.

Paul states that God's promises to Israel as a whole have not failed because of the rejection of the gospel by some of the Israelites. $^{23}$

\section{Meat (Noun)}

Sarx (sarc) has a broader meaning in the NT than in the OT. Its use in the New Testament can be analyzed as follows: "(a)" the substance of the body, "whether animal or human, 1 Corinthians 15:39; (b)"represents the human body," 2 Corinthians 10:3a; Gal 2:20; Phil 1:22; (c) "mankind," in the aggregate of all things essential to maturity, namely spirit, soul, and body, Matt. 24:22; John 1:13; Rom. 3:20; (d) states " holy mankind" of the Lord Jesus, in the whole of all that is essential to maturity, namely spirit, soul, and body John 1:14; 1 Tim 3:16; 1 John 4:2; 2 John 7, in Heb 5:7, "the days of his flesh", i.e. his past life on earth different from his current life in the resurrection; (e) for "a perfect man," John 6:51-57; 2 Corinthians 7:5; James 5:3; (f) "the weaker element in human nature," Matt. 26:41; Rom 6:19; 8:3a; (g) "the state of the unborn man," Rom 7:5; 8:8,9; (h) "the place of sin in man" (but this is not the same thing as in the body), 2 Peter 2:18; 1 John
$2: 16$; i) "the lesser and temporal element in the Christian," Gal 3:3; 6:8, and in religious ordinances, Heb 9:10; (j) "the natural attainment of man," 1 Cor 1:26; 2 Corinthians $10: 2,3 \mathrm{~b} ; \quad(\mathrm{k}) \quad$ "the circumstances," 1 Corinthians 7:28; external life, 2 Corinthians 7:1; Eph 6:5; Heb 9:13; (1) by metonymy, "outward and visible," as opposed to spirit, inward and manifest, John 6:63; 2 Corinthians 5:16; (m) "a natural relationship, which is not right," 1 Corinthians 10: 18; Gal 4:23, or marriage, Mt 19:5. "From Records on Galatia, by Hogg and Vine, pp. 111, 112. In Mt 26:41; Rom 8:4,13; 1 Corinthians 5:5; Gal 6:8 (not the Holy Spirit, here), "flesh" is contrasted with spirit, in Rom. 2:28,29, with heart and spirit; in Rom. 7:25, with mind; cf. Col. $2: 1.5$. This is augmented with thought in Eph 2:3, and with zeal in 2 Corinthians 7:1. 2. kreas denotes "meat" in the sense of flesh. It is used in the plural in Rom. 14:21; 1 Corinthians 8:13.

\section{Promise (Noun)}

Epangelia, especially the legal term, which denotes a "call" (epi, "upon," angello, "to announce, announce"), also means "an attempt to perform or give a promise." Except in Acts 23:21 it only used

${ }^{23} \mathrm{ME}$ Glasswell, Exegetical Dictionary Of The New Testament, PC Study Bible V5.0C for Windows. Computer Software. 
for God's "promise". It is often an abbreviation of what was "promised," and it signifies a gift that is generously given, not a promise guaranteed by negotiation; Thus, in Gal. 3:14, "the promise of the Spirit" denotes "the promised Spirit": cf. Luke 24:49; Acts 2:33 and Eph 1:13; So in Heb. 9:15, "the promise of an everlasting inheritance" is "a promised eternal inheritance." On the other hand, in Acts 1:4, "the promise of the Father," is the "promise" In Gal 3:16, the plural "promise" is used because the "promise" to Abraham is repeated over and over again. Gen. 12:1$3 ; 13: 14-17 ; 15: 18 ; 17: 1-14 ; 22: 15-18$, and because it contains the germs of all subsequent "promises"; cf. Rom 9:4; Heb $6: 12 ; 7: 6 ; 8: 6 ; 11: 17 ;$ Gal 3:1 is occupied by showing that the "promise" is dependent on faith and not on the fulfillment of the Law. The law is greater than, and lesser than, the "promise," and does not invalidate it, vv. 21; cf. 4:23,28. Again, in Eph. 2:12, "covenant of promise" does not denote different covenants, but a covenant renewed frequently, all centered in Christ as the "promised ordination", and consisting of blessings to be given through Him.

In 2 Cor. 1:20 the plural is used of every "promise" made by God: cf. Heb $11: 33$; in $7: 6$, a special "promise" is mentioned. For other applications of the word, see, Eph. 6:2; 1 Tim 4:8; 2 Team 1:1;
Heb 4:1; 2 Peter 3:4,9; in 1 John 1:5 some mss. Have this word, instead of angelia, "message." The occurrence of the word with regard to Christ and what is centered on Him, can be arranged under the headings (1) content of "promise," Acts 26:6; Rom 4:20; 1 John 2:25; (2) heirs, Rom 9:8; 15:8; Gal 3:29; Heb 11:9; (3) condition, Rom 4:13,14; Gal 3:14-22; Heb 10:36

Epangelma denotes "a promise made," 2 Peter $1: 4 ; 3: 13$

\section{noun (sperm)}

sperm, similar to speiro, "sow" ("sperm," "spermatic,"), Has the following uses, (a) agriculture and botany, Mt 13:24,27,32,1 Cor 15:38; 2 Corinthians 9:10; (b) physiological, Heb 11:11; (c) metaphorical and metonymy for "seed, offspring," (1) natural offspring, Matt. 22:24,25, "seed" John 7:42; 8:33.37; Acts 3:25; Rom 1:3; 4:13,16,18; 9:7 (twice), $8.29 ; 11: 1 ; 22 ; 16,19,29 ; 16 ; 11: 18 ; 17$; in verse 16, "He said no, And for the seed, as many as possible, but for one, and your seed, which is Christ," quoted from Gen. $13: 15$ and $17: 7,8$, there is a major stress on the word "seed", which refers to a person (here, Christ) in fulfilling promises to Abraham - a unique use of the singular. While the plural form "seed", neither in Hebrew nor in Greek, certainly more natural than English (not so familiar in the Scriptures of human descent; plural 
Journal Kerugma

E-ISSN: 2622-1039

P-ISSN: 2621-8038

occurrence is in 1 Sam; 8:15, plant), but if divine intent refers to Abraham's natural progeny, a word others can be selected in the plural, such as "children"; All such words, however, set aside, "seed" is chosen as one which can be used singly, in order to show that "seed" is the Messiah. Some rabbis even considered "seed", in Gen. 4:25 and Isa. 53:10, as referring to the Coming One. but if divine intent refers to Abraham's natural descendants, another word can be chosen in the plural, such as "children"; All such words, however, set aside, "seed" is chosen as one which can be used singly, in order to show that "seed" is the Messiah. Some rabbis even considered "seed", in Gen. 4:25 and Isa. 53:10, as referring to the Coming One. but if divine intent refers to Abraham's natural descendants, another word can be chosen in the plural, such as "children"; All such words, however, set aside, "seed" is chosen as one which can be used singly, in order to show that "seed" is the Messiah. Some rabbis even considered "seed", in Gen. 4:25 and Isa. 53:10, as referring to the Coming One.

Descendants were given to Abraham apart from natural means, so that through him the Messiah might come, and the point of the apostle's argument is that since the fulfillment of God's promises is guaranteed by Christ, only those "in Christ" can receive them; (2) spiritual offspring, Rom 4:16,18;
9:8; Here the "children of promise are counted for the seed" points, firstly, Isaac's birth does not correspond to ordinary nature but to divine promise, and, secondly, by analogy, to the fact that all believers are children of God by spiritual birth; Gal 3:29

As 1 John 3:9, "his seed endured in Him," it is possible to understand this as meaning that God's children (His "seed") abide in Him, and do not continue to commit (practice) sin (the kata work "commit" does not represent the original in this section). Alternatively, the "seed" signifies the principle of spiritual life as imparted to the believer, who abides in him without the possibility of disfellowshipping or extinction; The Son of God remains in eternal relationship with Christ, he who lives in sin never becomes so related, he does not have the principle of life in Him. This meaning fits the context and general tenor of Surat.

\section{CONCLUSION}

After doing research with steps of exegesis on Romans 9:6-16, the writer draws a conclusion which is the final result of this exegesis. God with all His omniscience and His sovereignty, He has established and controlled all things. In the word Proginosko (Proginosko) it relates to His omniscience in choosing, God knows the people $\mathrm{He}$ chooses. Omniscience 
Journal Kerugma

E-ISSN: 2622-1039

P-ISSN: 2621-8038

emphasizes not only prior knowledge but an active relationship between the foreknowledge and the foreknowledge. God chose them from the beginning even before the foundation of the world (Ephesians 1:4).

It should be noted that God is a powerful person who is very capable of carrying out all of His plans. The word oion estin oux describes the case the same as the word described (ekpeptoken), meaning that God's word (God's word) will not fail and will definitely happen.

God has fulfilled His promise to confirm His Word. The choice is not based on deeds but based on calling. God also shows His sovereignty over that choice, namely that what He has ordained from the beginning is what He fulfills. God's justice is also seen, namely that He does not look at appearances. Likewise, God's election of the Israelites did not depend on deeds, even their disobedience could thwart God's purposes for them as God's choice.

The election was only because of God's grace. The verb, participle, present active, genitive means it is not because humans have a longing, a will but only because : verb, participle, present active, genitive (belongs to Allah) which means because Allah is having mercy.

The nation of Israel, which God had chosen and ordained from the beginning, will continue to be God's chosen nation.
Indeed some of them have rejected Christ, but God will still fulfill that promise to the Israelites in the eschatological period. God will return to restore and save the nation of Israel. God never rejects His chosen people, because regarding their choice they are God's lovers.

\section{REFERENCES}

[1]. Abineno, Ch. JL Key Points of the Christian Faith. Jakarta: BPK Gunung Mulia.

[2]. Aritonang, Jan. S. What and How of the Church/Introduction to the History of Ecclesiology. Jakarta: BPK Gunung Mulia.

[3]. B. Ferguson, Sinclair. New Dictionary Of Theology - Volume 1. Malang: Literatur SAAT

[4]. B.S, Yusuf. Safety Can't Be Lost. 1996 [5]. Bakker, FL History of the Kingdom of God. Jakarta: BPK Gunung Mulia.

[6]. Analytical Greek New Testament" Michigan: Baker Book House.

[7]. Barclay, William. Daily Bible Understanding - Romans. Jakarta: BPK Gunung Mulia

[8]. Barth, Christoph. Old Testament Theology 1. Jakarta: BPK Gunung Mulia.

[9]. Beecher, Willis J. The Prophets and The Promise. Grand Rapids: Baker

[10]. Berkhof, Louis. Systematic Theology - Volume 1 The Doctrine of God. Indonesian Evangelical Reformed Institute, 1993. 
[11]. Church History. Jakarta: BPK Gunung Mulia.

[12]. Boersema A. Jan \& et al, XXI Century Theology. Perkantas Literature, 2015 [13]. Braga, James. How to Study the Bible. Malang: Gandum Mas Publisher.

[14]. Brill, J. Wesley. Solid Foundation. Bandung: Kalam Life Publisher.

[15]. Interpretation of the Epistle of Philippians. Bandung: Kalam Hidup Foundation.

[16]. Bruggen, Jakob Van. Who Made the Bible? The Completion and Authority of the Old and New Testaments. Surabaya: Momentum Publisher.

[17]. Buckner, Charles E. Exploration of God's Word/Book of Malachi. Bandung: Baptist Literature Institute.

[18]. Carson, DA \& Moo, Douglas J. An Introduction To The New Testament. Malang: Gandum Mas Publisher.

[19]. Carson, DA The Church of the New Testament and the Present. Malang: Gandum Mas Publishing Foundation.

[20]. Carlson, Raymond G. Safety. Malang: Gandum Mas Publisher.

[21]. Chapman, Adina. Introduction to the New Testament. Bandung: Kalam Hidup Foundation

[22]. Christoph, Barth. Old Testament Theology 1. Jakarta: BPK Gunung Mulia.

[23]. Chuk,Sung Wook.Learn Systematic Theology Easily. Contents Press.

[24]. Collins, Gerald O, SJ. Theological Dictionary. Yogyakarta: 1995
[25]. Conner, Kevin J. The Epistel To The Romans Commentary. USA: City Bible Publishing. 